\title{
Discussion on Chinization of Marxist Mass View
}

\author{
Wenqi Zeng ${ }^{1,2}$ \\ ${ }^{1}$ Marxism School, Sichuan University, Chengdu, 610064, China \\ ${ }^{2}$ Development and Planning Department, Chengdu University of Technology,
}

Chengdu, 610059, China

\begin{abstract}
Keywords: Marxist mass view, Mass line, Chinization experience
\end{abstract}
\begin{abstract}
Marxist mass view reflects in a concentrated way Marx's view on fundamental political stand of the proletarian party. To persist in Marxist mass view, the Chinese Communist Party is required to show full respect for the masses' dominant position in practical work. With Marxist mass view as the object of research, the author made a detailed discussion from three aspects: connotation, chinization course and chinization experience of Marxist mass view.
\end{abstract}

\section{Introduction}

Marxism is one of guiding thoughts of the Chinese Communist Party. Marxist mass view is of great importance for political work of the CCP. After its introduction to China, Marxist mass view also keeps continuous development with social development in China. The CCP's leaders deeply rooted Marxist mass view in practical development of Chinese society, and continuously enriched the theory of Marxist mass view. Therefore, strengthening the study of connotation and essence of Marxist mass view is one of basic requirements of enhancing the CCP's persistence in mass line. At the same time, it is also an important approach used to improve the CCP's mass work capacity.

\section{Basic Connotation of Marxist Mass View}

For cognition of Marxist mass view, we can roughly understand from the following two aspects: firstly, viewed from its source, Marxist mass view includes not only basic views of Marx, Engels, Lenin and other persons but also basic views of Chinese leaders like Mao Zedong, Deng Xiaoping and Jiang Zemin. Secondly, viewed from its content, Marxist mass view includes the contents of world outlook as well as the contents of methodology. Therefore, to strength the research on Marxist mass view plays an important role in guiding the CCP's work in the new period. To be specific, the connotation of Marxist mass view can be understood from the following aspects:

Firstly, Marx thought that history was created by the masses "11. According to Marxist historical materialism, practice is an important approach used to transform objective world and subjective world. However, human's practical activities are developed under certain social environment. Therefore, human's practical activity is the basis for social history. Quantitatively, the masses take up the biggest proportion in social members. Qualitatively, Marx thought that the reason for continuous social development was mainly the masses' force. Therefore, Marx said that history was created by the masses. At first, Marxist mass view points out that material wealth in the society is created by the masses. According to Marx, the masses created production of physical materials in social practice, which decided the masses' dominant position in social practice. Second, Marxist mass view also points out that spiritual wealth of the society is created by the masses. No matter we are in whichever times, human's thoughts, scientific \& artistic activities and any other spiritual wealth are outcomes from the masses' practice. Third, the masses promoted social reform. No matter in whichever times, the fundamental driving force for social progress and reform is inevitably the masses.

Secondly, Marx thought that the proletarian party should take "serving the people wholeheartedly" as its purpose ${ }^{\mathbf{2} 2 \mathbf{1}}$. This view mainly includes the following two aspects: first, Marx thought that service of the proletarian party should be wholehearted. All works of the proletarian 
party must be centered on the people's interests. In case of any issues related to the people's interests, the proletarian party should solve these issues as the most important things, and maintain the people's interests by various effective measures. Second, Marx thought that service of the proletarian party should consider the people's current interests and long-term interests.

Thirdly, Marx thought that the proletarian party should learn from the masses ${ }^{\mathbf{I} 3 \mathbf{l}}$. According to Marx, the proletarian party's policies made in the stages of revolution, construction and reform are sourced from the masses. At the same time, various correct opinions and propositions of the proletarian party in daily work are also from the masses. Personal ability will always be limited by various factors, but the people's intelligence is infinite. Therefore, Marx thought that the proletarian party should persist in mass line, so as to master richer work experiences and serve the people in a better way.

\section{Chinization Course of Marxist Mass View}

When applied in practical cases in China, Marxist mass view must be combined with actual national conditions of China, so as to solve specific issues in Chinese revolution, construction and reform. Generally speaking, chinization course of Marxism can be roughly divided into the following three stages:

\section{Period of new democracy}

Period of new democracy is the beginning stage of chinization of Marxist mass view. In this period, Mao Zedong and other leaders carefully analyzed practical national conditions of China, and established the general line of “overturning imperialism, feudalism and bureaucrat capitalism” ${ }^{\mathbf{I} 4}$. To achieve this goal, the CCP's leaders formulated the guideline of “contact the masses, depend on the masses, and mobilize the masses” according to Marxist mass view. In the period of Liberation War, Mao Zedong definitely proposed to serve the people wholeheartedly, center on guarantee of the people's interests for all works of the CCP, and persist in mass line on the $7^{\text {th }}$ NPC. Finally, the mass line was established on the $7^{\text {th }}$ NPC. This line also becomes a fine tradition and style of work of the CCP in its future works.

\section{Period of socialist construction}

Period of socialist construction is the development stage of chinization of Marxist mass view. After the establishment of new China, the CCP's regime was faced with new tests. On the $2^{\text {nd }}$ Plenary Session of the $7^{\text {th }}$ CPC Central Committee, Mao Zedong pointed out that Chinese revolution would have a long way to go. Therefore, the CCP should effectively utilize the tool of Marxist criticism and self-criticism, and maintain traditional style of the CCP.

In early years of the new nation, Zedong pointed out that construction of socialist undertakings was the undertaking of all Chinese people. Therefore, the CCP must depend on the people to construct socialism. Thus, the CCP's ruling status can be continuously consolidated and promote better achievement of socialist undertakings. Therefore, the CCP should also cherish its power, and utilize the power given by the people to do practical things for the people.

After the establishment of new China, China's economy got rapid development because of the reform in various aspects. As a result, some Party members got bureaucratic style of work, leading some people to have negative emotions for the Party's work. To effectively solve this issue, Mao Zedong promoted chinization of Marxist mass view from the following aspects: first, systematically, Mao Zedong thought that the CCP allowed long-term coexistence between Democratic Party and the CCP. Both parties should implement mutual supervision and seek for common development. Second, Mao Zedong recommended establishing the system of people's congress and the political consultation system in China. Thus, the people's opinions can be participated into policy decision making, making the CCP to make more scientific requirements conforming to the people in a better way. Third, Mao Zedong recommended implementing the system of democratic centralism in China. At the same time, the CCP is required to have timely understandings of the people's demands. Thus, the CCP's good image can be established. Moreover, the masses can effectively supervise the works of Party cadres. At last, Mao Zedong addressed the force of supervision by public opinions. Once 
serious bureaucratic or any other adverse styles take place in the Party, the CCP should utilize the medium tool of newspaper for wide disclosure.

\section{Period of Socialist reform and opening-up}

Period of Socialist reform and opening-up is the maturity stage of chinization of Marxist mass view. After the $3^{\text {rd }}$ Plenary Session of the $11^{\text {th }}$ Central Committee of the CCP, central leaders represented by Deng Xiaoping combined social missions at that time, and made proper innovations to our system. These innovative policies are all centered on the people's needs. The CCP tried the best to meet the people's requirements. Therefore, these innovative policies influentially redeployed the people's enthusiasm. Deng Xiaoping took the people's interests as the center and whether the CCP's policy could improve the people's living standards as an important measurement criterion.

Leaders represented by Jiang Zemin proposed the thought of "three represents". The essence of this thought is that the CCP's ruling should be based on realization of the people's interests, and continuously meet the people's increasing material and cultural needs ${ }^{\mathbf{5} \mathbf{I}}$. The masses are creators of advanced productivity and advanced culture in China. Therefore, the CCP should take realization of the people's fundamental interests as the basis for development of advanced productivity and advanced culture, so as to make the people to really become beneficiaries of these achievements.

Central leaders represented by $\mathrm{Hu}$ Jintao proposed the thought of "scientific outlook on development". This thought is established on the basis of people orientation. It comes down in one continuous line with Marxist mass view. At the same time, this thought is also effective combination with practical development of contemporary China. In this thought, Hu Jintao addressed that the most important reason for the CCP's establishment and continuous development was support from the people. Therefore, the CCP should take the people's needs as the starting point at any time and maintenance of the people's legitimate rights and interests as the center of all works.

\section{Basic Chinization Experience of Marxist Mass View}

\section{Treat Marxism in a scientific way}

After its introduction to China, Marxist mass view wins supports from Party leaders. Under the guidance of Marxist mass view, they led Chinese people to construct new socialist China. In this process, however, Party leaders gave full play to the function of Marxist mass view after continuous modifications to this theory. While applying Marxist mass view in practical construction of China, we must absorb by adhering to the dialectical attitude. This already becomes an important experience for promotion of chinization of Marxist mass view.

In the application process, we cannot use any dogmatic mode or completely perform according to theoretical requirements. On the contrary, we should supplement and absorb basic theory of Marxist mass view, and combine actual conditions of China to continuously enrich and develop Marxist mass view. Thus, the function of Marxist mass view can be given full play to in the construction of China.

\section{Treat Marxist mass view by keeping pace with the times}

Society is continuously changing. Peace and development have already become themes of the present times. Great changes take place in both form and mission facing the CCP. Therefore, the present CCP should take its ruling conditions as the basis for its research on Marxist mass view. According to practical requirements, the CCP should also continuously enrich and improve Marxist mass view. This already becomes an important experience used to promote chinization of Marxist mass view.

In the period of new democratic revolution, Mao Zedong combined Marxist mass view with China's new-democratic revolution practice. On this basis, he summarized the Party's mass line, and proposed the masses' opinions. Nowadays, we should also adopt this mode for application of Marxist mass view. We should enrich Marxist mass view according to the requirements of times, and properly abandon some views inconformity with the requirements of times in Marxist mass view, so as to continuously add some theories conforming to national conditions of China. This makes chinization of Marxist mass view to continuously adapt to Chinese development needs. At the same time, it also 
makes internal life of Marxist mass view to be more vivid, so as to have better guidance significance to China's socialist construction and effectively promote China’s development.

\section{Emphasize study and education of Marxist mass view}

Enriched by Chinese leaders in various terms, Marxist mass view continuously adapts to practical development of China. In the continuous chinization process of Marxist mass view, the CCP always lays special emphasis on study of the theory of Marxist mass view. Through careful study of Marxist mass view, Party members memorized it in the heart, and applied this theory into practice, so as to guide their practical actions. This has already become an important experience used to promote chinization of Marxist mass view ${ }^{\mathbf{I} 6 \mathbf{1}}$.

In the Report to the Eighteenth National Congress of the Communist Party, the CCP definitely pointed out that we must continuously deepen the development of mass education for Party members in the current stage. No matter Chinese society develops into whatever stage, the CCP must bear in mind that the people's interests should be put in the first place. We should depend on the people's force to promote development of Chinese history. At the same time, the CCP must do practical things for its people, maintain its honesty, and take maintenance of its honesty as the main content of its work. Moreover, the CCP should also positively develop education work of mass line in daily work, and improve its consciousness of centering on the people, enabling each Party cadre to take settlement of practical issues in the people's life and work as the most concerned issue and to properly finish affairs related to the people in the current society.

\section{Conclusion}

To sum up, Marxist mass view is the methodology used by the CCP to effectively solve the most concerned issues of the masses. Therefore, the CCP must continuously deepen Marxist mass view, and continuously enrich the theory of Marxist mass view by combining practical development of China. Thus, the CCP's reigning position can be consolidated, so as to promote the construction of socialist modernization in China.

\section{References}

[1] Yang Jiuhua and Zhang Dengguo, Chinization of Marxist Mass View and Reflection on Mass Work Pattern Conversion, Guangxi Social Sciences, 2014;

[2] Jiang Xiaoping and Jiang Jiancheng, Marxist Mass View and Its Realization Route, Truth Seeking, 2014;

[3] Wen Lihong, Historical Evolution of Marxist Mass View, Intelligence, 2013;

[4] Wang Fengxiang and Hong Niande, Thought of Marxism Chinization, Modernization and Popularization under the View of Theoretical Innovation, Guangxi Social Sciences, 2013;

[5] Feng Denan, Discussion on the CCP’s Inheritance and Development of Marxist Mass View, Bridge of Century, 2011;

[6] Zhang Yangli, Analysis on Marxist Mass View and Its Practical Significance, Chinese Times, 2014 